\title{
Analisis Kemampuan Komunikasi Matematis Siswa Autistik Berat dalam Menyelesaikan Soal Matematika
}

\author{
Syifa Kamilah ${ }^{1}$, Subhan Ajiz Awalludin ${ }^{2}$ \\ ${ }^{1,2}$ Program Studi Pendidikan Matematika, Fakultas Ilmu Pendidikan, Universitas Muhammadiyah Prof Dr. Hamka, \\ Jl. Tanah Merdeka No 20, Jakarta Timur, Indonesia \\ syifakamilah98@email.com
}

\begin{abstract}
Limited communication skills are one of the obstacles for people with autism in interacting with their environment. Especially in learning mathematics. This study aims to describe the written mathematical communication skills of severe autistic students in solving math problems. The research subjects are two severe autistic students in one of the special autistic learning houses. Subject selection using purposive sampling technique. The research method used is a descriptive qualitative approach. The research instrument consisted of observation, math test sheets and interviews. The results showed that the two subjects in this study have different written mathematical communication skills. The first subject has a medium written mathematical communication skills category while the second subject has very low written mathematical communication skills, The written mathematical skill of each autistic students is different depending on their respective abilities. The role of the assistant teacher in understanding mathematics.
\end{abstract}

Keywords: Autistic Student, Mathematical Communication Skill

\begin{abstract}
Abstrak
Keterbatasan kemampuan komunikasi menjadi salah satu hambatan bagi penyandang autisme dalam berinteraksi dengan lingkungannya. Khususnya dalam pembelajaran matematika. Penelitian ini bertujuan untuk menganalisis kemampuan komunikasi matematis tulis pada pada siswa autistik berat dalam menyelesaikan soal matematika. Subjek penelitian adalah dua siswa autistik berat di salah satu rumah belajar khusus autistik. Pemilihan subjek menggunakan teknik purposive sampling. Metode penelitian yang digunakan adalah pendekatan kualitatif deskriptif. Instrumen penelitian terdiri dari observasi, lembar tes soal matematika dan wawancara. Hasil penelitian menunjukan kedua subjek pada penelitian ini memiliki perbedaan kemampuan komunikasi matematis tulis. Subjek pertama memiliki kategori kemampuan komunikasi matematis tulis tinggi sedangkan subjek kedua memiliki kemampuan komunikasi matematis tulis sangat rendah. Kemampuan komunikasi matematis tulis pada tiap siswa autistik berbeda tergantung masing-masing kemampuan yang dimilikinya. Peran guru pendamping sangat dibutuhkan siswa autistik dalam memahami soal matematika.
\end{abstract}

Kata kunci: Siswa Autistik, Kemampuan Komunikasi Matematis

Copyright (c) 2021 Syifa Kamilah, Subhan Ajiz Awalludin

$\triangle$ Corresponding author: Subhan Ajiz Awalludin

Email Address: subhanajiz@uhamka.ac.id (Jl. Tanah Merdeka No 20, Jakarta Timur)

Received 05 July 2021, Accepted 15 July 2021, Published 02 August 2021

\section{PENDAHULUAN}

Anak dengan penyandang autisme memiliki gangguan perkembangan yang sangat kompleks dalam pertumbuhan seperti dalam hal komunikasi (Febriyanti \& Irawan, 2018). Keterbatasan alam pikir yang dimiliki para penyandang autisme juga mempengaruhi kemampuan dalam memahami dunia dari sudut pandang orang lain (Rohmani Nur Indah, 2017). Sehingga cenderung komunikasi hanya berjalan satu arah. Ciri-cirinya dapat terlihat sejak anak berusia kurang dari 3 tahun (Griadhi et al., 2016). Menurut Diagnostic and Statistical Manual of Mental Disorder V (DSM V) 2 ciri utama pada autisme yaitu: (1) Komunikasi sosial dan interaksi sosial, (2) Minat yang terbatas dan perilaku yang berulang. Salah satu contoh pada hambatan komunikasi sosial, anak autisme cenderung menarik diri ketika berinteraksi dengan teman sebayanya dikarenakan ketidakmampuan dalam membaca sinyal-sinyal nonverbal serta sulit untuk menyampaikan umpan balik. Akibatnya kekurangan dalam kemampuan membentuk hubungan sosial, 
komunikasi yang normal dan perubahan perilaku. Kemampuan komunikasi siswa autistik dapat berkembang tergantung pada penanganan yang diberikan sejak masa kanak-kanak hingga remaja (Wijayaptri, 2015).

Anak dengan gangguan autisme berat berada pada gangguan autisme yang sangat parah. Kemampuan berkomunikasi dan berinteraksi yang sangat sedikit bahkan mustahil dapat dilakukan menjadi hambatan besar dalam proses perkembangannya. Ketidakmampuan dalam melalukan suatu perintah yang diberikan salah satunya dikarenakan kemampuan pendengaran yang masih kurang. Kurangnya empati terhadap sesama dikarenakan keterbatasan dalam mengatur emosi baik bagi dirinya sendiri maupun orang lain. Respon yang kurang tepat atau bahkan tidak sama sekali menjadi salah satu tanda anak memiliki gangguan autisme berat Sehingga sangat dibutuhkan dukungan besar untuk dapat melakukan kegiatan sehari-hari minimal untuk dirinya sendiri.

Setiap warga negara berhak mendapatkan pendidikan tanpa melihat kekurangan dan kelebihan yang ada padanya. Sebagaimana dalam Undang-Undang Nomor 20 Tahun 2003 tentang sistem pendidikan pasal 5 ayat 2 "Warga negara yang memiliki kelainan fisik, emosional, mental, intelektual dan atau sosial berhak memperoleh pendidikan khusus". Hal ini menunjukan bahwa setiap anak, termasuk anak berkebutuhan khusus berhak mendapatkan pendidikan salah satunya anak autistik. Pemberian kelas khusus pada anak autisik akan lebih membantu proses belajar mereka (Febriyanti \& Irawan, 2018). Dua anak yang sama-sama didiagnosa autisme dapat menunjukan perilaku dan kemampuan yang tidak sama (Rohmani Nur Indah, 2017). Artinya anak autistik memiliki ciri kepribadian dan kemampuan yang khas. Sehingga proses belajarnyapun perlu dilakukan secara khusus. Salah satunya yaitu menggunakan guru pendamping. Peran guru pendamping juga dapat membantu meningkatkan kemampuan komunikasi matematis dan interaksi sosial siswa autistik dengan orang lain (Ritonga \& Hasibuan, 2016).

Salah satu kemampuan dasar dalam pembelajaran matematika yaitu kemampuan komunikasi matematis. Kemampuan komunikasi matematis adalah kemampuan siswa dalam menyampaikan ide matematika baik secara lisan seperti diskusi dan menjelaskan maupun kemampuan komunikasi matematis tulisan seperti mengungkapkan ide matematika melalui gambar/grafik, tabel, persamaan, ataupun dengan bahasa siswa sendiri. (Hodiyanto, 2017). Adapun indikator kemampuan komunikasi matematis tulis menurut Sumarmo (2012): (1) Menghubungkan benda nyata, gambar, dan diagram ke dalam ide matematika; (2) Menjelaskan ide, situasi dan relasi matematik secara tulisan dengan benda nyata, gambar, grafik dan aljabar; (3) Menyatakan peristiwa sehari-hari dalam bahasa atau simbol matematika. Kemampuan komunikasi matematis siswa terlihat dalam proses pembelajaran matematika di kelas.

Menurut Peklari (2019) kemampuan matematika pada penyandang autisme cenderung dapat terjadi karena dipengaruhi oleh alat yang digunakan dan materi yang sederhana. Materi matematika sederhana biasanya disajikan dalam bentuk konkrit baik simbol maupun gambar. Bentuk soal cerita akan lebih sulit dipahami oleh siswa autistik khususnya siswa autistik berat. Siswa autistik berat memiliki keterbatasan dalam pemahaman masalah matematika (Fauziyah et al., 2020). Sehingga pemilihan materi matematika harus disesuaikan dengan tingkat kemampuan siswa autistik tersebut. Peran guru pendamping dalam 
Analisis Kemampuan Komunikasi Matematis Siswa Autistik Berat dalam Menyelesaikan Soal Matematika, Syifa Kamilah Subhan Ajiz Awalludin

memahami keadaan psikologis siswa dapat membantu berjalannya proses pembelajaran matematika. Sejalan dengan Siregar (2017) menyatakan bahwa siswa dapat belajar matematika apabila materi yang dipelajarinya sesuai dengan tingkat berpikir anak dan keadaaan psikologis siswa.

Penelitian pendahuluan yang dilakukan di salah satu rumah belajar khusus autistik didapati bahwa kemampuan komunikasi matematis siswa autistik masih kurang khususnya pada siswa autistik berat. Kebanyakan yang bersekolah disini adalah anak-anak penyandang autisme yang tidak dapat bersekolah di sekolah inklusi maupun sekolah formal khusus penyandang autisme. Kegiatan belajar mengajar guru SLB di dalam kelas dilakukan dengan menggunakan pendekatan yang lembut seperti guru mengajar siswanya seperti kakak sedang mengajarkan adiknya guna membantu proses belajar siswa autistik dalam mengerjakan tugas-tugasnya (Dewi \& Muthmainnah, 2016). Selain kegiatan pembelajaran di kelas, di SLB untuk siswa autistik terdapat kegiatan terapi yang disesuaikan dengan kebutuhan siswa, salah satunya terapi wicara (Daroni et al., 2018). Kegiatan pembelajaran khusus tersebut bila dilakukan dengan tepat dapat menghasilkan perkembangan yang bertahap dan harapannya siswa dengan spektrum autisme akan bisa menyamai atau mendekati anak-anak lainnya yang tidak mengalami masalah, khususnya pada pembelajaran matematika dalam hal kemampuan komunikasi matematis.

Penelitian tentang kemampuan komunikasi matematis siswa autistik yang telah dilakukan salah satunya menurut Anggia (2015) siswa penyandang autisme cenderung tidak mampu dalam mengekspresikan pemahaman matematiknya dalam komunikasi matematis. siswa penyandang autisme cenderung tidak mampu dalam mengekspresikan pemahaman matematiknya dalam komunikasi matematis. Seperti dalam pemahaman konsep hitung perkalian pada siswa autistik di kelas 11 masih kurang (Dewi \& Muthmainnah, 2016). Berbeda dengan Syarifudin et al. (2017) dalam penelitiannya pada 2 siswa autistik kelas VIII di sekolah inklusi secara keseluruhan dapat mencapai indikator kemampuan komunikasi matematis. Peklari (2019) menyatakan siswa dengan gangguan autisme kesulitan dalam memahami matematika dikarenakan faktor gangguan spektrum autisme itu sendiri, sehingga umur tidak menjadi acuan dalam mengukur kemampuan individu autisme. Pembelajaran matematika dapat dilakukan pada lembaga sekolah khusus formal maupun informal seperti rumah terapi. Penelitian terkait pembelajaran siswa autistik selain di sekolah inklusi juga bisa menjadi topik yang menarik untuk dilakukan. Sejalan dengan Rahmawati (2018) penelitian terkait proses pembelajaran matematika tidak sebatas di dalam sekolah inklusi saja.

Berdasarkan pemaparan di atas, peneliti tertarik untuk melakukan penelitian tentang kemampuan komunikasi matematis tulis pada siswa autistik berat di salah satu rumah belajar khusus autistik dalam menyelesaikan soal matematika.

\section{METODE}

Penelitian ini menggunakan metode pendekatan kualitatif bersifat deskriptif untuk menganalisis kemampuan komunikasi matematis tulis siswa autistik berat dalam menyelesaikan soal matematika. Teknik pengambilan sampel yang digunakan adalah purposive sampling dengan tujuan memperoleh subjek penelitian sesuai dengan pertimbangan tertentu (Sugiyono, 2018). Berdasarkan keterangan dari guru 
pendamping terpilih dua siswa autistik berat yaitu Siswa Autistik Berat 1 (SAB1) dan Siswa Autistik Berat 2 (SAB2) di salah satu rumah belajar khusus autistik.

Instrumen utama dalam penelitian kualitatif adalah peneliti itu sendiri yang berperan besar dalam seluruh proses penelitian mulai dari pemilihan topik, mengumpulkan data sampai merepresentasikan hasil analisis data (Dr. Wahidmurni, 2017). Instrumen lain yang digunakan yaitu lembar observasi kemampuan komunikasi matematis tulis, lembar soal tes berupa 6 soal matematika materi penjumlahan dan pengurangan yang telah divalidasi oleh ahli serta pedoman wawancara.

Teknik analisis data melalui tahapan pengumpulan data seperti lembar jawaban subjek, rekaman video ketika subjek mengerjakan lembar soal dan hasil wawancara mengenai langkah-langkah menyelesaikan soal tes. Data yang telah terkumpul direduksi yakni berfokus pada keterangan guru pendamping mengenai kemampuan komunikasi matematis tulis siswanya. Kemudian data kemampuan komunikasi matematis tulis yang dimiliki siswa autistik disajikan dalam bentuk tabel hingga tahap penarikan kesimpulan kemampuan komunikasi matematis tulis pada subjek tersebut.

\section{HASIL DAN DISKUSI}

Berikut data hasil analisis kemampuan komunikasi matematis tulis pada 2 siswa autistik berat di salah satu rumah belajar khusus autistik:

Tabel 1. Hasil Analisis Data

\begin{tabular}{|c|l|c|c|}
\hline \multirow{2}{*}{$\begin{array}{c}\text { Nomor } \\
\text { Soal }\end{array}$} & \multirow{2}{*}{ Indikator Kemampuan Komunikasi Matematis Tulisan } & \multicolumn{2}{|c|}{ Rekapitulasi Perolehan } \\
\cline { 3 - 4 } & & SAB 1 & SAB 2 \\
\hline 1 & $\begin{array}{l}\text { Menghubungkan benda nyata, gambar, dan diagram ke dalam ide } \\
\text { matematika. }\end{array}$ & 4 & 2 \\
\hline 2 & $\begin{array}{l}\text { Menjelaskan ide, situasi dan relasi matematik secara tulisan } \\
\text { dengan benda nyata, gambar, grafik dan aljabar. }\end{array}$ & 2 & 2 \\
\hline 3 & $\begin{array}{l}\text { Menyatakan peristiwa sehari-hari dalam bahasa atau simbol } \\
\text { matematika. }\end{array}$ & 4 & 1 \\
\hline 4 & Total Skor & 20 & 1 \\
\hline 5 & Persentase & $83,3 \%$ & 3 \\
\hline & Kategori & Tinggi & Sangat Rendah \\
\hline
\end{tabular}

\section{Indikator Menghubungkan Benda Nyata, Gambar dan Diagram ke dalam Ide Matematika}

Berikut ini tampilan salah satu soal dan jawaban kemampuan komunikasi matematis tulis menghubungkan benda nyata, gambar dan diagram ke dalam ide matematika.

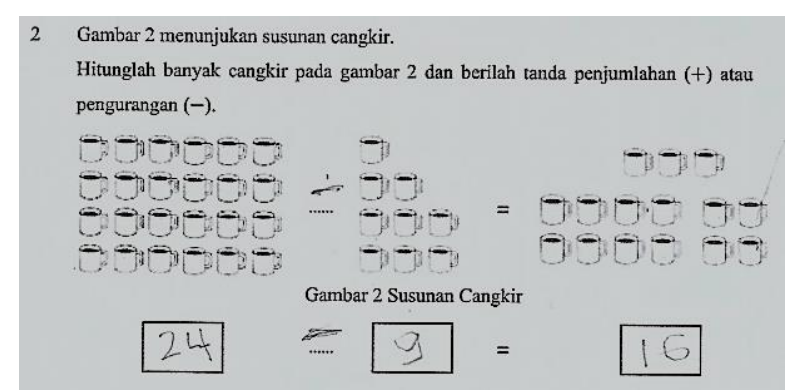

Gambar 1 Soal dan Jawaban Nomor 2 SAB 1 
Berdasarkan Gambar 1 dan hasil pengamatan rekaman video, SAB 1 dapat menghitung jumlah gambar dengan benar dan menuliskannya ke dalam simbol angka, dalam menentukan opersai hitung SAB 1 melihat kembali soal sambil sesekali melihat ke arah guru pendamping dan melihat ke arah lainnya. Guru pendamping memberi arahan kepada SAB 1 kemudian SAB 1 menuliskan tanda pengurangan. Hal ini menunjukan SAB 1 dapat menghubungkan gambar ke dalam ide matematika berupa simbol angka dan operasi hitung dengan pendampingan guru.

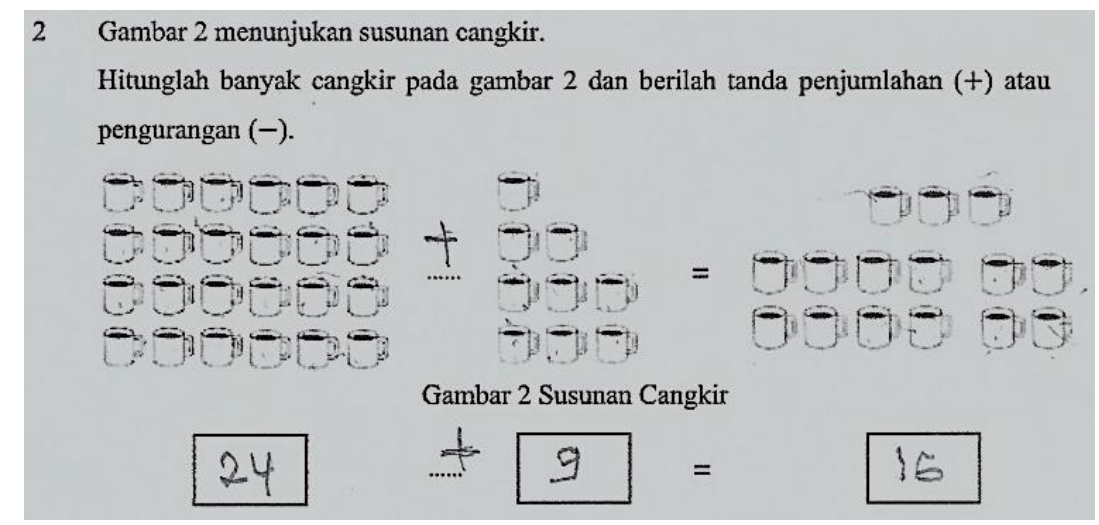

Gambar 2 Soal dan Jawaban Nomor 2 SAB 2

Sedangkan pada gambar 2 menunjukan SAB 2 belum tepat dalam menghitung gambar dan dan menuliskan angka. Guru pendamping juga memberikan arahan kepada SAB 2 dalam menghitung gambar karena SAB 2 tidak fokus dalam mengerjakan soal. Berbeda dengan SAB 1, SAB 2 tidak dapat menentukan operasi hitung dengan tepat. SAB 2 menuliskan tanda penjumlahan sambal melihat ke arah soal sebelumnya yang juga dijawab tanda penjumlahan olehnya. Hal ini menunjukan SAB 2 dapat menghubungkan gambar ke dalam ide matematika berupa simbol angka namun belum dapat menentukan operasi hitung.

\section{Indikator Menjelaskan Ide, Situasi dan Relasi Matematik Secara Tulisan dengan Benda Nyata, Gambar, Grafik Dan Aljabar}

Berikut ini tampilan salah satu soal dan jawaban kemampuan komunikasi matematis tulis menjelaskan ide, situasi dan relasi matematik secara tulisan dengan benda nyata, gambar, grafik dan aljabar.

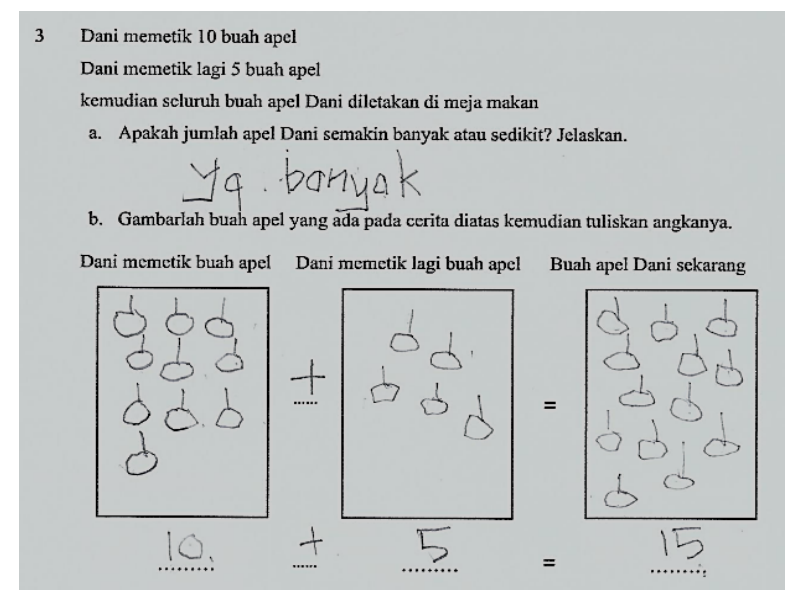

Gambar 3 Soal dan Jawaban Nomor 3 SAB 1 
Berdasarkan Gambar 3 SAB 1 tidak dapat menuliskan penjelasan jawaban nomor 3a sedangkan pada nomor 3a SAB 1 dapat menghitung gambar, menuliskan angka dan operasi hitung dengan tepat namun selama proses mengerjakan soal SAB 1 memerlukan bantuan dari guru pendamping dalam memahami maksud dari soal tersebut. Hasil pengamatan video menunjukan SAB 1 melihat kearah lain dan sesekali memainkan pensil yang dipegangnya. Hal ini menunjukan SAB 1 belum dapat menjelaskan situasi matematika pada soal ke dalam gambar dan angka dengan tepat namun kurang lengkap.

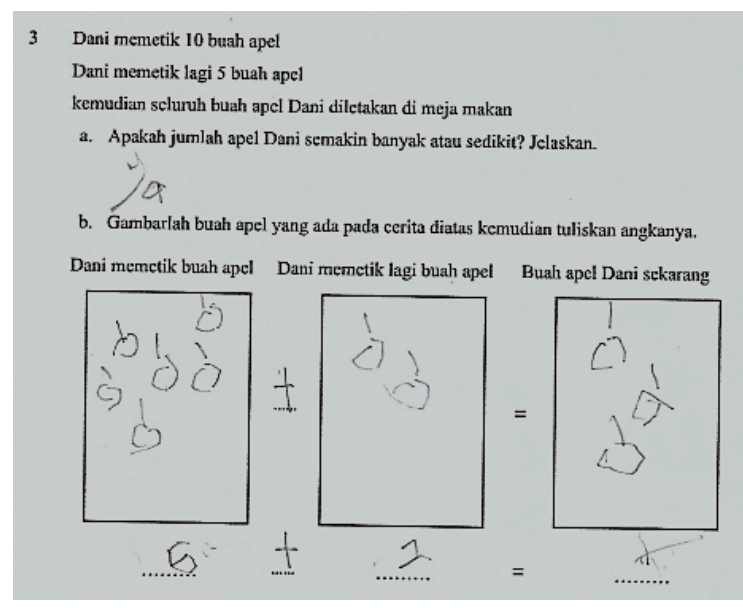

Gambar 4 Soal dan Jawaban Nomer 3 SAB 2

Sedangkan pada Gambar 4 SAB 2 tidak dapat menjawab nomer 3a. SAB 2 dapat menggambar benda dengan jumlah yang tidak tepat. Terlihat pada video rekaman selama mengerjakan soal SAB 2 tidak fokus membaca soal dan melihat ke arah lain ketika menuliskan jawabannya. SAB 2 menuliskan tanda penjumlahan sambil mengucapkan kata-kata dengan bahasa yang tidak dapat dimengerti orang lain. Guru pendamping membantu SAB 2 agar tetap fokus pada soal. Hal ini menunjukan SAB 2 belum dapat menjelaskan situasi matematika pada soal ke dalam gambar dan angka dengan lengkap dan tepat.

\section{Indikator Menyatakan Peristiwa Sehari-Hari dalam Bahasa atau Simbol Matematika}

Berikut ini tampilan salah satu soal dan jawaban kemampuan komunikasi matematis tulis menyatakan peristiwa sehari-hari dalam bahasa atau simbol matematika.

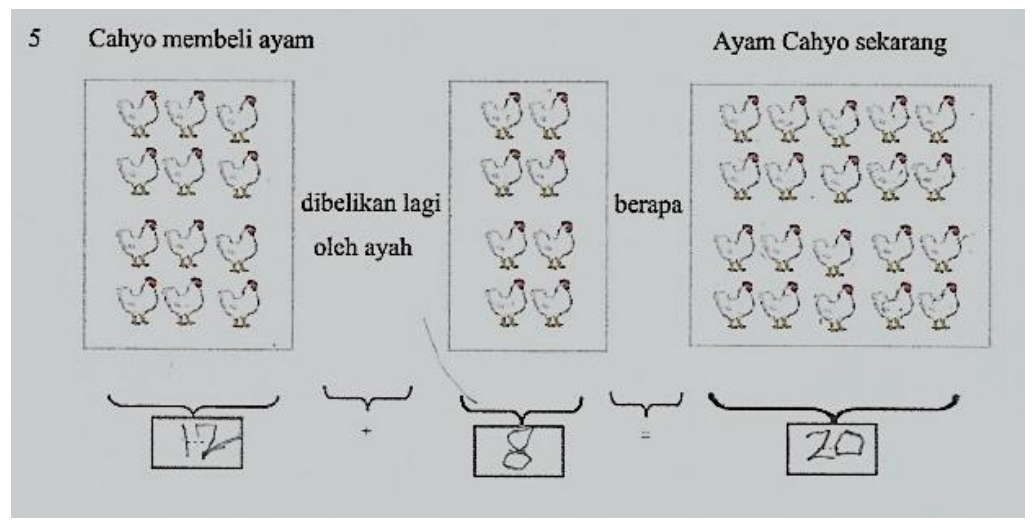

Gambar 5 Soal dan Jawaban Nomor 5 SAB 1 
Analisis Kemampuan Komunikasi Matematis Siswa Autistik Berat dalam Menyelesaikan Soal Matematika, Syifa Kamilah, Subhan Ajiz Awalludin

Berdasarkan lembar jawaban dan hasil pengamatan video, SAB 1 dapat menghitung banyaknya benda dan dapat menuliskan simbol matematika berupa angka banyaknya benda yang telah dihitung. Guru pendamping membantu SAB 1 memahami maksud perintah dalam soal dan mengarahkan dimana subjek harus menuliskan jawabannya. SAB 1 dapat menjawab dengan tepat banyaknya benda pada gambar dan dengan simbol matematika berupa angka yang tepat.

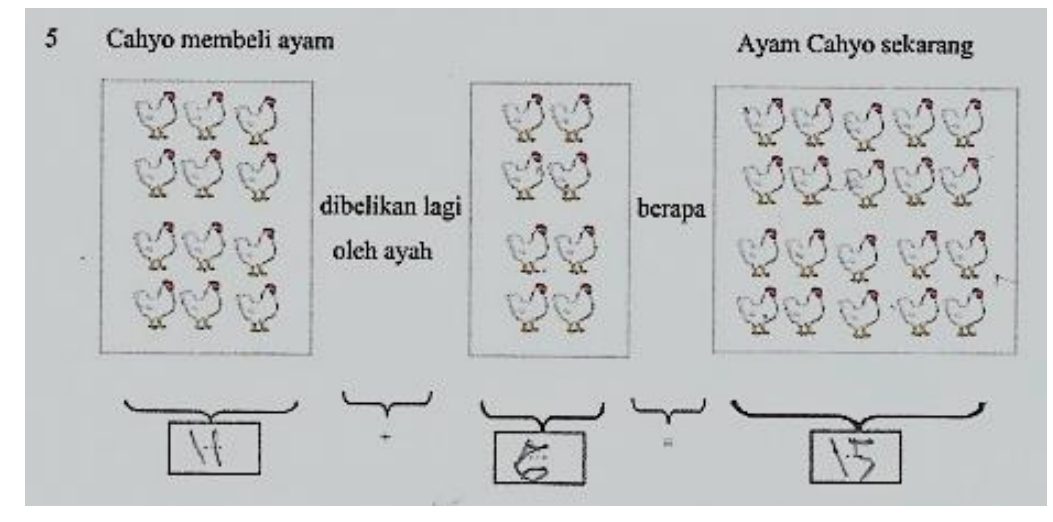

Gambar 6 Soal dan Jawaban Nomor 5 SAB 2

Sedangkan pada lembar jawaban SAB 2 menunjukan belum dapat menuliskan simbol matematika berupa angka banyaknya benda pada gambar walaupun sudah diberikan arahan dan bantuan dari guru pendamping dalam memahami soal. SAB 2 menghitung banyaknya benda dengan menunjuk gambar secara acak sehingga ada gambar yang tidak terhitung. SAB 2 menghitung sambil mengucapkan bahasa yang tidak dapat dimengerti. Hal ini menunjukan bahwa SAB 2 belum dapat menyatakan peristiwa sehari-hari yang diilustrasikan ke bentuk gambar dalam simbol matematika berupa angka dan kurang fokus dalam mengerjakan soal.

Berdasarkan hasil wawancara dan rekaman video menunjukan kedua subjek dalam penelitian ini tidak dapat menjawab dengan baik pertanyaan yang diajukan oleh peneliti. Peneliti dibantu oleh guru pendamping dalam memberikan pertanyaan mengenai langkah-langkah mengerjakan soal tes kemampuan komunikasi matematis tulis. Respon yang ditunjukan SAB 1 dan SAB 2 mengerjakan soal sambil melihat benda yang ada di sekelilingnya sesekali mengucapkan kata-kata yang diartikan oleh guru pendamping itu sebagai banyangan yang muncul di kepala subjek. Pada penderita autisme seringkali berbicara sendiri dengan bahasa yang tidap dapat dimengerti oleh orang lain (Nugraheni, 2012). Keterbatasan dalam komunikasi nonverbal seperti tidak adanya kontak mata, sulit memahami dan menggunakan bahasa tubuh ketika ingin mengungkapkan sesuatu ditunjukan pada penderita autisme menurut Diagnostic and Statistical Manual of Mental Disorder V (DSM V).

\section{KESIMPULAN}

Berdasarkan hasil penelitian di atas peneliti menyimpulkan bahwa: (1) Kemampuan komunikasi matematis tulis siswa autistik berat pada penelitian ini memiliki kemampuan yang berbeda, (2) Dari hasil 
perhitungan skor diperoleh SAB 1 memiliki kemampuan komunikasi matematis tulis tinggi sedangkan SAB 2 memiliki kemampuan komunikasi matematis tulis sangat rendah, (3) SAB 1 dan SAB 2 kurang fokus selama proses mengerjakan soal dan mendengarkan arahan dari guru pendamping, (4) ) Guru pendamping menjadi salah satu orang yang berperan penting dalam membantu perkembangan siswa autistik baik dalam hal pelajaran sekolah seperti matematika maupun pelajaran lain di rumah belajar khusus autistik ini seperti pelatihan kegiatan keseharian yang dapat membantu menstimulus siswa menjadi individu yang mandiri.

\section{REFERENSI}

Anggia, L. (2015). Analisis kemampuan komunikasi matematis berdasarkan teori Bruner pada pembelajaran matematika siswa autis di Sekolah Unggul Sakti. Seminar Nasional Matematika Dan Pendidikan Matematika UNY 2015, 1185-1190. http://seminar.uny.ac.id/semnasmatematika/sites/seminar.uny.ac.id.semnasmatematika/files/banner/P M-167.pdf

Daroni, G. A., Solihat, G., \& Salim, A. (2018). Manajemen Pendidikan Khusus di Sekolah Luar Biasa Untuk Anak Autis. Kelola Jurnal Manajemen Pendidikan, 5(2), 196-204. https://doi.org/10.24246/j.jk.2018.v5.i2.p196-204

Dewi, S. K., \& Muthmainnah, R. N. (2016). Profil Siswa Autis Dalam Pembelajaran Matematika Di Filial Slbn Bekasi Jaya. FIBONACCI: Jurnal Pendidikan Matematika Dan Matematika, 2(1), 69. https://doi.org/10.24853/fbc.2.1.69-77

Dr. Wahidmurni, M. P. (2017). Pemaparan Metode Penelitian Kualitatif. Repository Universitas Islam Negeri Maulana Malik Ibrahim Malang, 1-16.

Fauziyah, N., Budayasa, I. K., \& Juniati, D. (2020). Cognition processes of student with low functioning autism in solving mathematical problem. Journal of Physics: Conference Series, 1469(1). https://doi.org/10.1088/1742-6596/1469/1/012167

Febriyanti, C., \& Irawan, A. (2018). Pembelajaran Matematika pada Siswa Berkebutuhan Khusus di Sekolah Inklusi. Journal of Medives, 2(1), 99-106. https://doi.org/10.31331/medives.v2il.509

Griadhi, M. O. R., Ratep, N., \& Westa, W. (2016). Diagnosis dan Penatalaksanaan Autisme. E-Jurnal Medika Udayana, 2(11), 1-14. https://ojs.unud.ac.id/index.php/eum/article/view/7026

Hodiyanto, H. (2017). KEMAMPUAN KOMUNIKASI MATEMATIS DALAM PEMBELAJARAN MATEMATIKA. AdMathEdu: Jurnal Ilmiah Pendidikan Matematika, Ilmu Matematika Dan Matematika Terapan, 7(1), 9. https://doi.org/10.12928/admathedu.v7i1.7397

Nugraheni, S. A. (2012). Menguak Belantara Autisme. Buletin Psikologi, 20(1-2), 9-17. https://doi.org/10.22146/bpsi.11944

Peklari, E. (2019). Mathematical Skills in Autism Spectrum Disorder. AJAST (Asian Journal of Applied and Tecnology), 3(1), 111-123. https://doi.org/https://ssrn.com/abstract=3341658

Rahmawati, F. (2018). Pembelajaran Matematika pada Siswa Remaja dengan Kebutuhan Khusus di Sekolah Inklusi. Indonesian Journal of Mathematics Education, 1(1), 53-58. https://doi.org/10.31331/medives.v2i1.509 
Analisis Kemampuan Komunikasi Matematis Siswa Autistik Berat dalam Menyelesaikan Soal Matematika, Syifa Kamilah,

Ritonga, S. A., \& Hasibuan, E. J. (2016). Komunikasi Interpersonal Guru dan Siswa dalam Mengembangkan Bakat dan Kreativitas Anak Autis di SLB Taman Pendidikan Islam (TPI). JURNAL SIMBOLIKA: Research and Learning in Communication Study, 2(2), 188-199. https://doi.org/10.31289/simbollika.v2i2.1030

Rohmani Nur Indah. (2017). Gangguan Berbahasa: Kajian Pengantar. In UIN-Maliki Press.

Siregar, N. F. (2017). PSIKOLOGI DALAM PEMBELAJARAN MATEMATIKA. Logaritma: Jurnal Ilmu-Ilmu Pendidikan Dan Sains, 5(01), 16. https://doi.org/10.24952/logaritma.v5i01.1257

Sugiyono, P. D. (2018). Metode Penelitian Pendidikan: Pendekatan Kuantitatif, Kualitatif dan $R \&$ D. Alfabeta, Bandung.

Syarifudin, A., Sofnidar, \& Pasaribu, F. T. (2017). Analisis Kemampuan Komunikasi Matematis Siswa Autis dalam Menyelesaikan Soal Sistem Persamaan Linear Dua Variabel (SPLDV) di Kelas Inklusi SMPN 6 Kota Jambi. Repositori Universitas Jambi, 1-8.

Wijayaptri, N. W. P. (2015). Hambatan Komunikasi pada Penyandang Autisme Remaja: Sebuah Studi Kasus. Inklusi, 2(1), 41. https://doi.org/10.14421/ijds.020103 